Buana Sains Vol 18 No 1: 21 - 28, 2018

\title{
PENGARUH UMUR BATANG BAWAH DAN NAUNGAN TERHADAP KEBERHASILAN GRAFTING PADA TANAMAN DURIAN (Durio zibethinus Murr.) LOKAL
}

\author{
Hanif Fatur Rohman, Roedy Soelistyono dan Nur Edy Suminarti \\ Program Pascasarjana Universitas Brawijaya Malang
}

\begin{abstract}
Durian (Durio zibethinus Murr.) has a great sale value, besides its delicious flavor; it also contains the variety of nutrients such as vitamins B, C, E and Iron that are beneficial for human health. The main problems in improving the local durian are limited availability of quality seeds. Durian development undertaken by local farmers generally from generative, thereby causing the vegetative phase takes longer (about 7-10 years) and make generative phase come later. It is one of the obstacles to the productivity and quality of durian. It is one of the obstacles to the productivity and quality of durian. But with advances in technology, these obstacles can be overcome by using a mini-graft method to produce superior durian seedling. The purposes of this research are to get the right age and percentage of shade on grafted durian seedling and to determine the influence on growth and yield of grafted plants. This research conducted on January - Oktober 2016 on Durio Kingdom Farm, Ngantang, Malang Regency on 660 asl. The experiment was conducted using split plot design. The main plot is percentage shade $(\mathrm{N})$ : shade $0 \%$, shade $40 \%$, shade $60 \%$ and shade $80 \%$, while the subplots are seedlings (A) is 15 weeks age rootstock, 17 weeks age rootstock and 19 weeks age rootstock. The results of this study showed that 17 weeks Age seeds give better results, shade are gives better results for use in plant nurseries durian is shade with a density of $40 \%$.
\end{abstract}

Keywords: Grafting; durian; shade; chlorophyll; stomata

\section{Pendahuluan}

Durian (Durio zibethinus Murr.) mempunyai nilai jual yang cukup tinggi, selain rasa yang lezat, buah tersebut juga dilengkapi dengan berbagai nutrisi seperti vitamin $\mathrm{B}, \mathrm{C}, \mathrm{E}$ dan Zat Besi yang bermanfaat untuk kesehatan manusia. Produksi buah durian lokal Jawa Timur cenderung memperlihatkan terjadinya penurunan sebesar $20 \% \quad(12,180$ ton/tahun). Penurunan tersebut tidak hanya terjadi pada kuantitas, tetapi juga kualitasnya. Oleh karena itu untuk mengantisipasi terjadinya permasalahan yang lebih serius terhadap buah durian tersebut, maka perlu dicari akar permasalahan dan solusi yang efektif untuk penyelesaiannya. Pengembangan tanaman durian yang dilakukan oleh petani umumnya secara generatif (dari biji), sehingga menyebabkan fase vegetatif tanaman lebih panjang (sekitar 7-10 tahun lebih) baru memasuki fase generatif atau reproduksi. Teknologi perbanyakan yang disarankan dalam budidaya durian waktu cepat adalah mini grafting (sambung mini), yaitu teknik perbanyakan vegetatif yang dilakukan seawal mungkin pada kondisi batang 
H. F. Rohman, R. Soelistyono dan N. E. Suminarti/ Buana Sains Vol 18 No 1 : 21-28

bawah yang telah memungkinkan untuk disambung (Sugondo, 2001). Bibit unggul adalah tanaman muda yang memiliki sifat unggul yaitu mampu menunjukkan sifat asli induknya dan mempunyai nilai ekonomi yang tinggi, serta tidak mengandung hama dan penyakit. Pada tanaman buah sifat unggul ini terutama nilai dari kualitas buahnya. Bila semakin banyak sifat yang disukai konsumen terkumpul dalam satu buah, maka semakin tinggi pula nilai ekonomi (harga) buah tersebut.

Pohon induk adalah tanaman pilihan yang dipergunakan sebagai sumber batang atas (entres), baik itu tanaman kecil ataupun tanaman besar yang sudah produktif yang berasal dari biji atau hasil perbanyakan vegetatif. Persyaratan pohon induk antara lain 1) Memiliki sifat unggul dalam produktifitas dan kualitas buah untuk tanaman buah dan ketahanan terhadap serangan organisme penggangu tanaman (OPT), 2) Nama varietas pohon induk dan asalusulnya (nama pemilik, tempat asal) harus jelas, sehingga memudahkan pelacakannya, 3) Tanaman dari biji harus sudah berproduksi minimal lima musim, untuk mengetahui kemantapan sifat yang dibawanya, 4) Ditanam dalam kebun yang terpisah dari tanaman lain yang dapat menjadi sumber penularan penyakit atau penyerbukan silang, terutama untuk pohon induk yang akan diperbanyak secara generatif yaitu diambil bijinya (Prastowo dan Roshetko, 2006). Sadhu (1989) menyatakan bahwa penggunaan dan pemilihan tipe batang atas yang baik dan mengetahui kapan batang bawah berada dalam stadia aktifitas vegetatif yang baik merupakan pertimbangan penting berhasilnya penyatuan sambungan. Maka perlu diketahui umur batang bawah yang paling sesuai untuk disambung pada masingmasing varietas.Pada proses perbanyakan tanaman dengan penyambungan atau grafting, peranan batang bawah dalam menentukan keberhasilan sambungan dan pertumbuhan bibit hasil sambungan sangat besar. Pertumbuhan batang bawah yang optimal akan dapat meningkatkan keberhasilan dari hasil penyambungan dan pertumbuhan bibit hasil sambungan. Pertumbuhan bibit sebagai batang bawah sangat dipengaruhi oleh lingkungan tumbuhnya, yaitu media tanam, radiasi matahari, nutrisi, dan zat pengatur tumbuh (Barus, 2000). Unsur radiasi matahari yang penting bagi tanaman ialah intensitas cahaya, kualitas cahaya, dan lamanya penyinaran. Bila intensitas cahaya yang diterima rendah, maka jumlah cahaya yang diterima oleh setiap luasan permukaan daun dalam jangka waktu tertentu rendah (Gardner et al., 1991). Kondisi kekurangan cahaya berakibat terganggunya metabolisme, sehingga menyebabkan menurunnya laju fotosintesis dan sintesis karbohidrat (Chowdury et al., 1994 ; Sopandie et al., 2003).

\section{Metode Penelitian}

Penelitian dilaksanakan pada bulan Januari - Oktober 2016. Penelitian ini dilaksanakan di kebun durian "Durio Kingdom" yang terletak di Desa sumberagung, Kecamatan Ngantang, Kabupaten Malang, dengan ketinggian 660 mdpl. Penelitian dilaksanakan dengan menggunakan Rancangan Petak Terbagi (RPT). Sebagai petak utama adalah persentase naungan $(\mathrm{N})$ yakni Naungan $0 \%$, Naungan $40 \%$, Naungan $60 \%$, dan Naungan $80 \%$ selanjutnya sebagai anak petak adalah umur bibit (A) yakni bibit umur 15 minggu, bibit bawah umur 17 minggu dan bibit umur 19 minggu. Perlakuan dalam penelitian ini adalah 12 perlakuan, dimana setiap perlakuan terdapat 6 tanaman dan diulang sebanyak 3 kali, sehingga 
H. F. Rohman, R. Soelistyono dan N. E. Suminarti/ Buana Sains Vol 18 No 1 : 21-28

terdapat 216 tanaman atau satuan percobaan. Data hasil pengamatan dianalisis dengan menggunakan analisis ragam (uji F) pada taraf 5\%, dan apabila terdapat interaksi atau pengaruh nyata dari perlakuan, maka dilanjutkan dengan uji BNT pada taraf $5 \%$ untuk mengetahui perbedaan di antara perlakuan.

\section{Hasil dan Pembahasan}

Perlakuan perbedaan umur bibit yang akan di sambung bertujuan untuk mengetahui umur berapa yang paling efektif utuk dilakukan penyambungan agar sambungan dapat menempel dan menyambung dengan baik dan memiliki kompatibilitas tinggi, serta perlakuan pemberian naungan bertujuan untuk membuat kondisi lingkungan saat penyambungan tidak terlalu ekstrim, karena apabila kondisi lingkungan ekstrim maka bisa menyebabkan kegagalan proses penyambungan. Cruz (1997) menyatakan naungan dapat mengurangi enzim fotosintetik yang berfungsi sebagai katalisator dalam fiksasi CO2 dan menurunkan titik kompensasi cahaya. Prinsip pemberian naungan sedapat mungkin menekan terjadinya kondisi ekstrim lingkungan dan dapat memberikan pengaruh yang positif terhadap pertumbuhan dan keberhasilan sambungan.

\section{Pertambahan Panjang Tanaman Hasil Grafting}

Pertambahan panjang tanaman durian hasil grafting pada perlakuan umur bibit dan persentase naungan menunjukan bahwa pertambahan paling tinggi di dapatkan pada perlakuan umur bibit 17 minggu dan perlakuan naungan 40\% dibandingkan dengan perlakuan lainnya. Hal ini mengindikasi bahwa perbedaan umur bibit yang digunakan dan pemberian naungan yang berbeda dapat memberikan pengaruh yang berbeda pula pada penampilan tanaman secara morfologi.

Hal ini mengindikasi bahwa perbedaan umur bibit yang digunakan dan pemberian naungan yang berbeda dapat memberikan pengaruh yang berbeda pula pada penampilan tanaman secara morfologi. Agar mampu beradaptasi pada lingkungan dengan intensitas cahaya rendah, tanaman mengalami berbagai perubahan pada tingkat molekuler, biokimia, anatomi, morfologi, fisiologi, dan agronomi (Sopandie et al. 2001, Juraimi et al. 2004). Hal ini di pengaruhi oleh intensitas cahaya matahari, Intensitas cahaya tinggi berpengaruh terhadap aktivitas auksin pada meristem apikal. Apabila intensitas cahaya tinggi maka aktivitas auksin meningkat pula, pada naungan sedang yakni 40\% dapat mengurangi terjadinya kondisi lingkungan yang ekstrim sehingga tanaman bisa tumbuh dengan baik. Dengan pertumbuhan yang baik maka otomatis seluruh energi yang dihasilkan oleh tanaman akan terkonsentrasi pada penyembuhan luka pada sayatan dengan cara pembentukan kalus. Semakin cepat pembentukan kalus akan semakin cepat pula penyatuan antara batang atas dan batang bawah. Apabila batang aatas dan batang bawah sudah menyatu maka proses translokasi unsur hara serta nutrisi dari batang bawah ke batang atas akan berjalan dengan lancar dan baik. Menurut Harjadi (1993) bahwa ketersediaan unsur hara terutama nitrogen akan memacu pembentukan asam amino. Asam amino yang terbentuk akan tergabung membentuk protein melalui sederetan reaksi kompleks yang diatur asam nukleat dalam sel. Tempat pokok sintesa protein yang terjadi dalam jaringan dimana sel baru terbentuk, seperti tunas, kambium, pucuk, ujung akar dan jaringan penyimpanan yang sedang berkembang. 


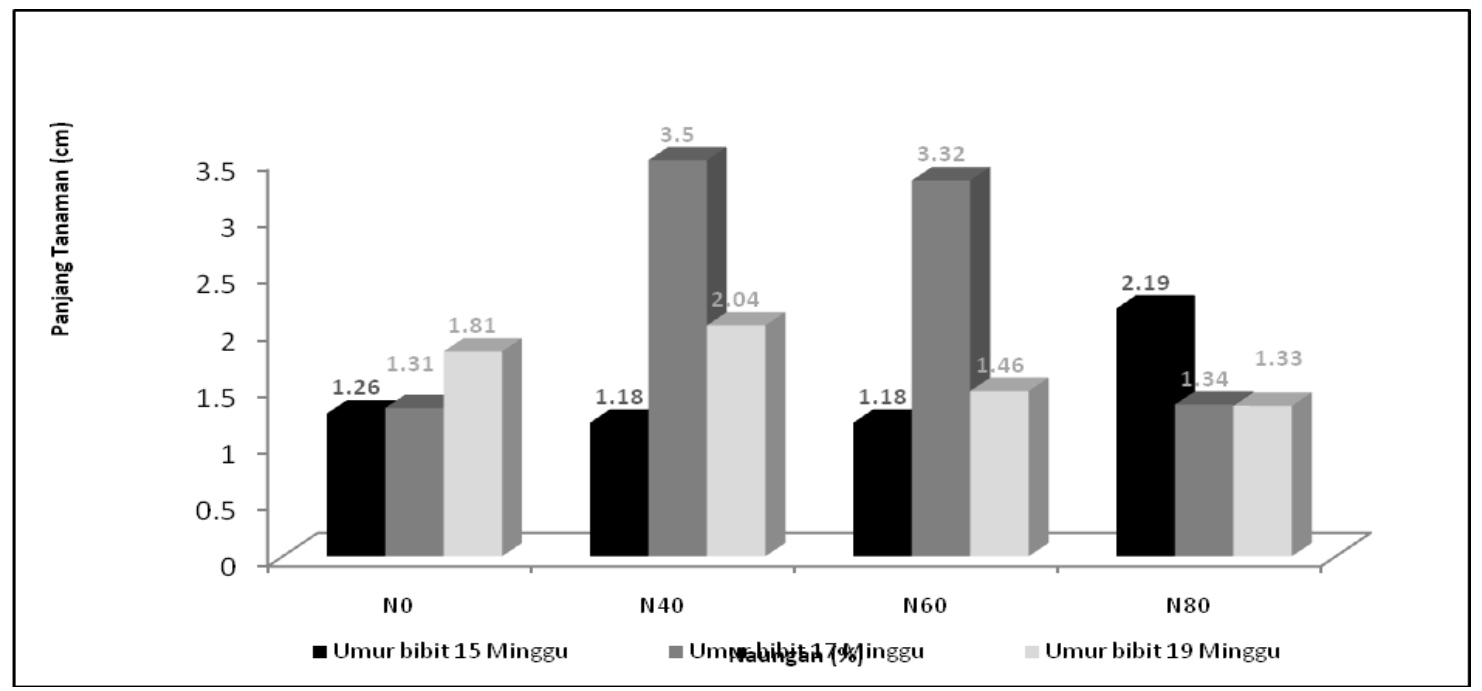

Gambar 1. Pengaruh naungan dan umur bibit terhadap panjang tanaman durian

\section{Keberhasilan Grafting}

Gambar 2 menunjukkan bahwa jumlah keberhasilan grafting memiliki jumlah yang berbeda setiap perlakuan naungan, pada naungan $40 \%$ menunjukkan hasil grafting paling tinggi yakni sebesar 30 tanaman. Tingkat keberhasilan sambung pada penelitian ini tergolong rendah yang mana keberhasilan grafting hanya $44,44 \%$. Naungan sangat mempengaruhi keberhasilan grafting hal ini disebabkan karena naungan dapat mempengaruhi iklim mikro pada lokasi penyambungan, dan keberhasilan sambungan sangat dipengaruhi oleh kondisi lingkungan. Terutama pada faktor suhu, yang mana suhu sangat berperan penting dalam proses pertautan jaringan pada tanaman grafting. Semakin rendah suhu maka proses pertautan jaringan juga akan semakin tinggi, oleh karenanya pada kondisi suhu yang sedang atau tidak terlalu tinggi akan menyebabkan tingkat keberhasilan yang tingg, hal ini dapat dilihat dari Gambar 2. pada perlakuan naungan $0 \%$ keberhasilan grafting lebih rendah dibanding dengan perlakuan pemberian naungan yang lain. Menurut Prastowo et al. (2006) pada proses pembibitan tanaman hanya dibutuhkan jumlah radiasi matahari antara $30-60 \%$. Oleh karena itu, untuk mengatur radiasi yang sampai ke tanaman diperlukan naungan.

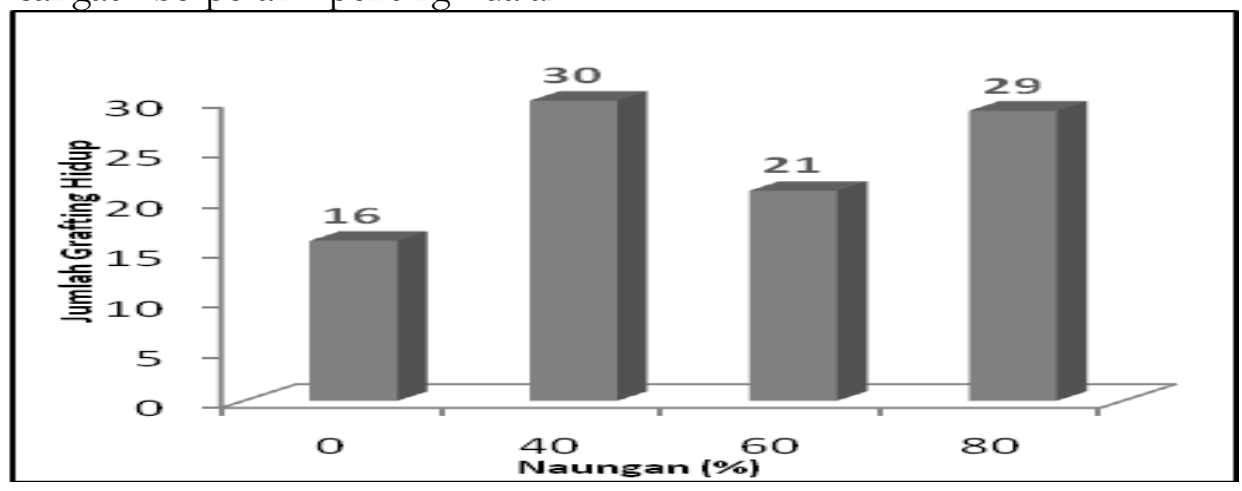

Gambar 2. Pengaruh persentase naungan terhadap keberhasilan grafting 
H. F. Rohman, R. Soelistyono dan N. E. Suminarti/ Buana Sains Vol 18 No 1 : 21-28

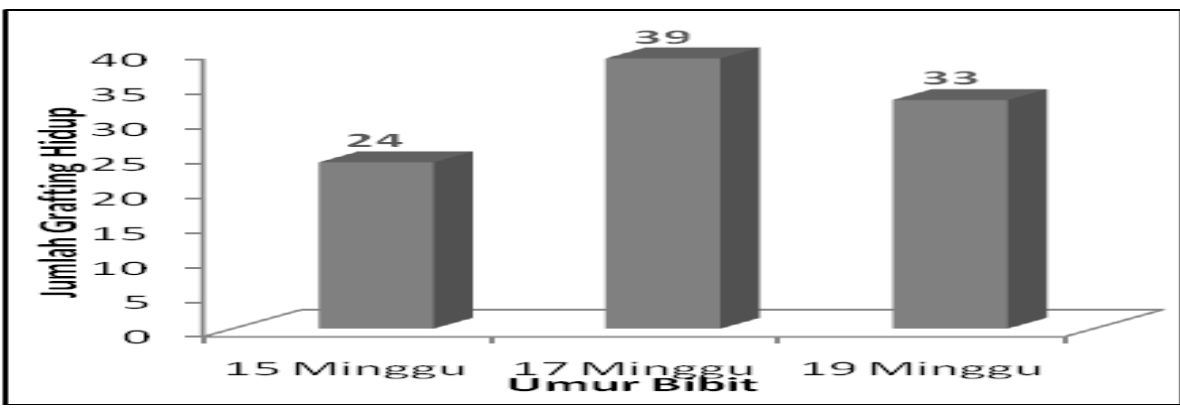

Gambar 3. Pengaruh persentase naungan terhadap keberhasilan grafting

Tingkat keberhasilan sambung pada penelitian ini tergolong dalam tingkat keberhasilan rendah, yang mana keberhasilan grafting hanya 44,44\%. Banyak faktor yang mempengaruhi keberhasilan sambung diantaranya kekerabatan tanaman yang akan digunakan sebagai batang atas dengan tanaman yang digunakan sebagai batang bawah, faktor lingkungan serta pelaksanaan yang mencakup proses pemotongan entris, pemotongan sambungan dan pemeliharaan sambungan. Pertautan sambungan juga sangat di tentukan kompatibilitas antara batang bawah dan batang atas, pada penelitian banyak kegagalan terjadi akibat inkompatibilitas sambungan yang disebabkan batang atas atau entris banyak yang memiliki ukuran yang lebih besar dibanding batang bawah yang mana menyebabkan posisi jaringan tidak manyatu sehingga translokasi air dan nutrisi tidak terjadi sehingga menyebabkan batang atas tidak mendapatkan suplai nutrisi dan akhirnya mengalami kegagalan. Tambing et. al., (2009) menyatakan bahwa umur bibit bawah berpengaruh nyata terhadap presentase keberhasilan sambungan.

\section{Kandungan Klorofil}

Berdasarkan hasil uji laboratorium kandungan klorofil daun durian pada semua perlakuan menunjukkan bahwa kandungan klorofil tertinggi terdapat pada tanaman durian dengan perlakuan naungan $40 \%$ dan semakin besar persentase naungan yang diberikan menyebabkan semakin rendah pula kandungan klorofil baik klorofil a, klorofil b dan klorofil total. Namun pada kontrol atau perlakuan tanpa naungan menunjukkan hasil klorofil yang lebih rendah apabila dibandingkan dengan perlakuan naungan $40 \%$.

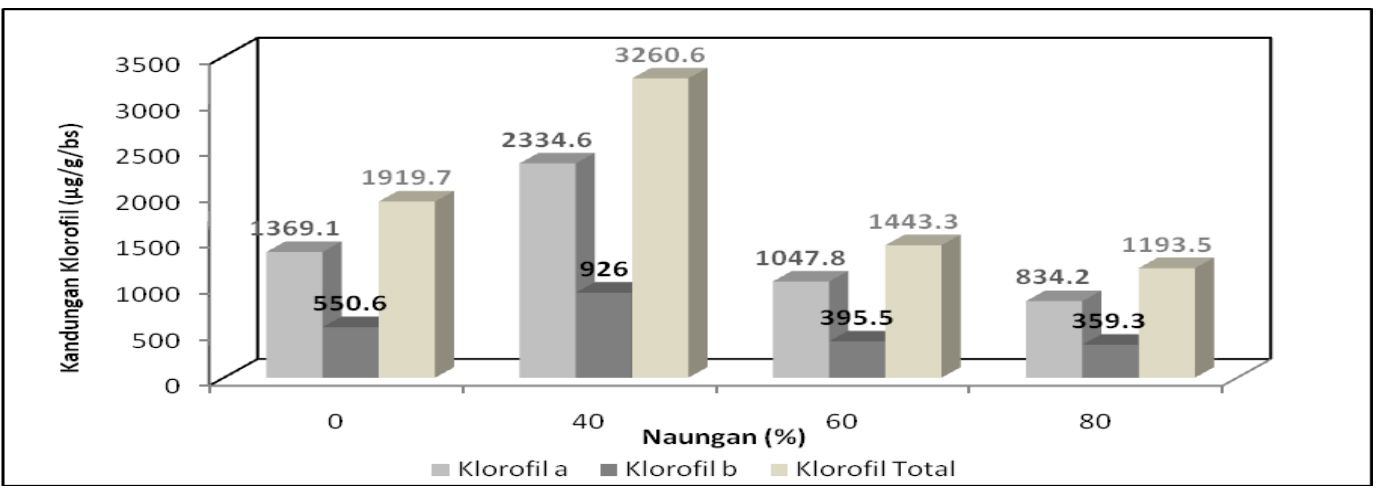

Gambar 4. Kandungan klorofil pada berbagai naungan 
H. F. Rohman, R. Soelistyono dan N. E. Suminarti/ Buana Sains Vol 18 No 1 : 21-28

Gambar 4 menunjukkan bahwa klorofil a paling tinggi terdapat pada naungan $40 \%$, sedangkan pada klorofil $\mathrm{b}$ menunjukkan kandungan paling tinggi terdapat pada perlakuan naungan $40 \%$ begitu juga dengan klorofil total. Oleh karena itu dapat diketahui bahwa semakin tinggi intensitas cahaya maka kadar klorofil pada tanaman juga akan semaik tinggi. Namun disisi lain, intensitas cahaya yang tinggi juga dapat menyebabkan menurunnya kadar klorofil daun seperti pada perlakuan tanpa naungan yang memiliki kandungan klorofil lebih rendah dari pemberian perlakuan naungan $40 \%$. Hal ini menunjukkan bahwa pada naungan 40\% kandungan klorofil merupakan paling tinggi diantara pemberian naungan yang lainnya. Pada naungan 40\% merupakan naungan optimum untuk pertumbuhan tanaman hasil sambungan pada kondisi naungan $40 \%$ intensitas cahaya yang diterima oleh tanaman berada pada intensitas yang tepat oleh karenanya kandungan klorofilnya juga menunjukkan yang paling baik. Bila intensitas cahaya yang diterima rendah, maka jumlah cahaya yang diterima oleh satuan luas permukaan daun dalam jangka waktu tertentu rendah (Gardner et al., 1991). Daniel et al. (1979) menerangkan bahwa proses fotosintesis, cahaya berpengaruh melalui intensitas, kualitas dan lamanya penyinaran, tetapi yang terpenting adalah intensitasnya. Hal ini disebabkan karena intensitas cahaya yang semakin tinggi (naik) mengakibatkan lalu fotosisntesis semakin tidak bertambah lagi walaupun intensitas cahaya terus bertambah. Batas ini disebut titik saturasi cahaya atau titik jenuh cahaya (ligh saturation point). Pada keadaan ini cahaya bukan sebagai sumber energi maupun sebagai bentuk, tetapi sebagai perusak (foto destruktif). Intensitas cahaya yang tinggi mengakibatkan temperatur daun meningkat, sebagai akibat menutupnya stomata, sehingga sebagaian klorofil menjadi pecah dan rusak (fotodestruktif) (Soekkotjo, 1977). Hal ini sesuai dengan pendapat Kramer dan Kozlowneski (1979) bahwa kandungan klorofil tanaman di bawah naungan lebih besar per satuan berat kering dibandingkan dengan tanaman yang terbuka, mempunyai daun yang lebih tebal, sehingga volumenya lebih besar per satuan luas.

\section{Kerapatan Stomata}

Semakin tinggi intensitas cahaya, maka kerapatan stomata semakin tinggi. Hasil yang didapatkan ini sesuai dengan pernyataan Fahn (1991) dalam Paluvi (2015) bahwa semakin tinggi intensitas cahaya, kerapatan stomata di kedua permukaan daun semakin meningkat. Kerapatan dan jumlah stomata yang banyak merupakan proses adaptasi dari tanaman terhadap kondisi lingkungannya. Intensitas cahaya mempengaruhi suhu lingkungan.

Semakin tinggi intensitas cahaya, maka suhu lingkungan semakin tinggi. Pembukaan dan penutupan stomata salah satunya dipengaruhi oleh suhu lingkungan. Gambar 5 menunjukkan hubungan antara perlakuan naungan dan kerapatan stomata. Terlihat bahwa semakin tinggi intensitas cahaya, maka kerapatan stomata juga akan semakin tinggi. Pada setiap kenaikan kerapatan naungan diikuti dengan penurunan kerapatan stomata, hal ini merupakan mekanisme tanaman untuk untuk beradaptasi terhadap kondisi lingkungan untuk mempertahankan diri. 


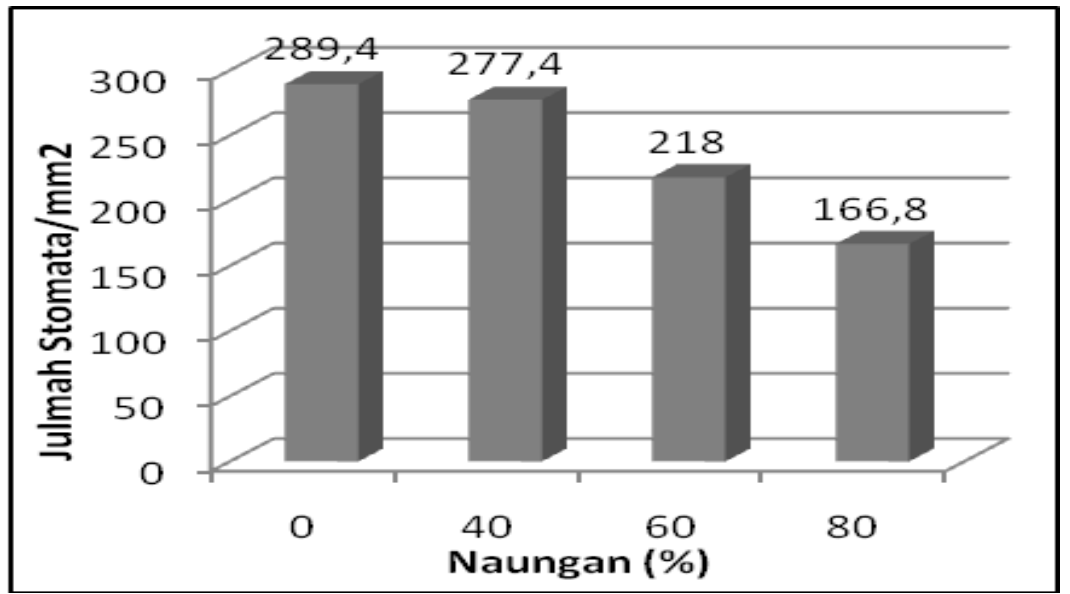

Gambar 5. Jumlah stomata pada berbagai persentase naungan

Fitter dan Hay (1992) menyatakan bahwa respon stomata terhadap naungan merupakan adaptasi tanaman terhadap perubahan lingkungan untuk menghambat difusi $\mathrm{CO}_{2}$ Selain itu pada tingkat cahaya rendah konsentrasi $\mathrm{CO}_{2}$ antarsel dapat menjadi pengendali utama dalam fotosintesis (Salisbury dan Ross, 1995). Hal ini berakibat pada menurunnya pertumbuhan tanaman pada jenis-jenis tumbuhan yang tidak toleran terhadap naungan seperti pula pada penelitian ini. Pada tanaman kopi, jumlah stomata daun tanaman yang tumbuh pada kondisi cahaya penuh lebih banyak dibandingkan dengan jumlah stomata pada daun kopi yang ternaungi (Morais et al., 2004). Percobaan dengan daun irish yang ditumbuhkan pada cahaya berbedabeda memperlihatkan bahwa jumlah stomata berkurang dengan menurunnya intensitas cahaya (Pazourek, 1970).

\section{Kesimpulan}

Pemberian naungan dan umur bibit yang berbeda memberikan pengaruh yang berbeda pula, terbukti dengan adanya interaksi pada pengamatan pertambahan panjang tanaman. Umur bibit 17 minggu memberikan hasil yang lebih baik daripada umur bibit 15 dan 19 minggu.
Berdasarkan hasil penelitian didapatkan naungan yang memberikan hasil lebih baik untuk digunakan dalam pembibitan tanaman durian ialah naungan dengan kerapatan $40 \%$.

\section{Daftar Pustaka}

Barus, A. dan Syukri. 2008. Agroteknologi Tanaman BuahBuahan. USU Press. Medan. p. 23

Chowdury P. K., ThangarajM.and Jayapragasam. 1994. Biochemical Changes in Low Irradiance Tolerant and Succeptible Rice Cultivars. Biol. Plantarum. 36(2): 237- 242

Cruz, P. 1997. Effect of Shade on the Growth and Mineral Nutrition of C4 Perennial Grass under Field Conditions. J. Plant and Soil 188:227-237

Daniel, T.W., Helm, J.W. and F.S. Baker. 1979. Principles of Silvicultur, 2 nd. Mc.Grow Hill Inc. New York.p. 45

Fitter, A. H.and Hay, R. K. M. 1992. Environmental Physiology of Plant. Gadjah Mada University Press. p. 237 
H. F. Rohman, R. Soelistyono dan N. E. Suminarti/ Buana Sains Vol 18 No 1 : 21-28

Gardner, F. P., Pearce, R. B. and R. L. Mitchell. 1991. Physiology of Crop Plants. Jakarta. Universitas Indonesia Press. p. 24

Harjadi, W. 1993. Ilmu Kimia Analitik Dasar. Jakarta. Gramedia Pustaka Utama. p. 32

Juraimi, A. S., Drennan, D. S. H. and Anuar N. 2004. The Effects of Shading on the Growth, Development and Partitioning of Biomass in Bermudagrass (Cynodon dactylon (L.) Pers). J. Biol. Sci. 4:756-762

Kramer, P. J., and T. T.Kozlowski.1979. Physiology of Woody Plant. Academic Press, New York. p. 169

Morais, H., Medri,M. E., Marrur,C. J., Caramon,P. H., Ribeiro,A. M. A.and Gomes,J. C. 2004. Modofication on Leaf Anatomy of Coffea Arabica Caused by Shade of Pigeonpea (Cajanus cajan). Brazilian Archives of Biology and Tech. 47(6):863-871

Paluvi., Niken., Mukarlina dan Linda,R.2015. Struktur Anatomi Daun, Kantung dan Sulur Nepenthes Gracilis Korth yang Tumbuh di Area Intensitas Cahaya Berbeda. J. Protobiont, 4(1): 103-107

Pazourek. 1970. in: A Fahn. 1995. Plant Anatomy. Third Edition. Diterjemahkan R. M. T. Koesoemaningrat, $\mathrm{M}$. Natasaputra dan H. Akmal. Gadjah Mada University Press

Prastowo, N., Roshetko,J.M., Maurung,G. E. S., Nugraha, E., Tukan,J. M. dan Harum,F. 2006.Tehnik Pembibitan dan Perbanyakan Vegetatif Tanaman
Buah.World Agroforestry Centre (ICRAF) dan Winrock International. Bogor, Indonesia. p. 5-9

Sadhu, M. K.1989. Plant Propagation.Wiley Eastern Limited.New Delhi. India. p. 21

Salisbury, F. B. and Ross, C. W. 1995. Plant Physiology. Diterjemahkan oleh DR Lukman dan Sumarjono. ITB Bandung.

Sugondo, B. dan Sugiharto. 2001.Teknik Pembibitan Tanaman Hartikultura dan Pemeliharaan. Balai Penelitian Getas.Salatiga. 34 p.

Tambing, Y., dan S. Launde. 2009. Kajian Umur Bibit Bawah Nangka dan Takaran Pupuk Pelengkap benih Nutrifarm-SD terhadap Keberhasilan Pertautan sambungan Pucuk. Agroland 16(1): 33-39 